\title{
Informal business and poverty in South Africa: Re-thinking the paradigm ${ }^{1}$
}

\author{
MARLESE VON BROEMBSEN \\ Senior Lecturer, Faculty of Law, University of Cape Town
}

\section{INTRODUCTION}

Among the foundational values of our democracy are "human dignity, the achievement of equality and the advancement of human rights and freedoms". 2 Sen's theory of development is helpful to understand the interrelationship between dignity, freedom, rights and equality. He challenges the "narrower" view that equates development with "growth of gross national product, or rise in personal incomes, or industrialisation or with technological advance, or social modernisation". 3 He reframes development as "expanding" each person's "freedoms" to enable each person to live (with dignity) the life he or she wishes to live and, in particular, to participate in the social, political and economic life of his or her community. Sengupta adds that the expansion of these freedoms, in other words development, is a human right. ${ }^{4}$ Inherent in this understanding of development is the eradication of "un-freedoms", such as "poverty, poor economic opportunities and social deprivation", that constrain equal participation. ${ }^{5}$

Sen argues that

" $[t]$ his freedom-centred understanding of economics and of the process of development is very much an agent orientated view. With adequate social opportunities, individuals can effectively shape their own destiny and help each other." 6

Sen's belief that fostering agency is concomitant with people shaping their own destiny calls for careful scrutiny. As I will argue, market-based policies that claim to foster agency with the expectation that, therefore, in the words of a global aid agency, we can "eradicate poverty through the efforts of the poor themselves",

\footnotetext{
${ }^{1}$ I would like to acknowledge the helpful comments by Alan Rycroft and two anonymous referees on earlier drafts of this paper.

${ }^{2}$ Section 1(a) of the Constitution of the Republic of South Africa, 1996.

${ }^{3}$ A. Sen Development is Freedom (Random House, 1999) 3.

${ }^{4}$ A Sengupta "The Human Right to Development" in (2004) 32 Oxford Development Studies 179.

${ }^{5}$ Sen op cit 4 .

${ }^{6}$ Sen op cit 11.

${ }^{7}$ CARE Canada "Making Markets Work for the Poor: CARE Canada's Strategy for helping the Poor through Enterprise" (2004) 6.
} 
amount to little more than shifting what is rightfully government's responsibility to address structural inequalities to chronically poor people, who are most marginalised, to increase their participation in the economy.

For purposes of this article, chronic poverty is a descriptor for poverty that reflects a state of pervasive, unrelenting disempowerment and socio-economic vulnerability and marginality. The relationship between chronic and structural poverty is well articulated by Du Toit:

"Understanding who is likely to sink into poverty, who is likely to stay out of it for long periods of time, and who is able to make the investments required to ensure that a subsequent generation gets out (or stays out) of it requires not only the post-hoc tracking of actual welfare over time, but also an assessment of the underlying factors that shape their likely welfare. This means that the study of chronic poverty - and the identification of the chronically poor - is inseparable from the study of structural poverty and vulnerability." 8

This article critiques South Africa's policy on informal business. Specifically, I ask: does it have the potential to promote meaningful participation in the economy for those most marginalised? Does it take sufficient account of the "underlying factors" that shape the ability of those who are chronically poor to grow a business, or does it inadvertently relegate the chronically poor to marginal economic activities pursued as survival strategies? Is it enabling in the sense that it genuinely fosters agency on the part of chronically poor people? Or does it unwittingly perpetuate structural poverty?

The term "informal" is intended as shorthand for describing marginality rather than signaling allegiance to a particular understanding of the relationship between the formal and informal sectors or "economies"9.

The observation by Du Toit and Neves on the second economy discourse ${ }^{10}$ is helpful in underlining the limitation of dualistic "formal" versus "informal" thinking. The authors argue that the "power and importance" of former President Mbeki's construct of the "second economy", as an economy that functions separately, economically and spatially, from the "first economy",

\footnotetext{
${ }^{8}$ Andries du Toit "Poverty measurement blues: Some reflections on the space for understanding 'chronic'and 'structural' poverty in South Africa" Chronic Poverty and Development Policy Paper No 5 (PLAAS, 2005) at 6.

${ }^{9}$ See David Dewar "A Conceptual Framework for the Formulation of an Informal Trader Policy for South African Towns and Cities" Urban Forum vol 16 no 1 (2005) for a detailed discussion of President's Mbeki's first/second economy discourse and an analysis of the four different schools of thought on the relationship between the "formal" and "informal" sectors.

10 In 2003 President Thabo Mbeki introduced the now infamous term "second economy" into the formal/informal sector/economy discourse. The "first economy" / "second economy" dualism echoes the early ILO dualism that views the informal economy as distinct and separate from the formal economy, providing income generation opportunities for those unable to find employment in the formal economy.
} 


\begin{abstract}
"does not lie in the literal accuracy of what [it] says about the South African economy clearly the notion of the second economy as an entirely separate economic realm with its own internal flows, boundaries and central institutions is rather easy to discount but in its ability to provide a powerful and suggestive shorthand that can serve to name or frame the deeply segmented nature of South African society." 11
\end{abstract}

The fact that our society is deeply segmented and that this segmentation fundamentally impacts on the ability of the chronically poor to generate income, or on the potential of their marginal income-generation strategies to grow into viable businesses, is rarely explored in small, medium and micro-enterprise (SMME) literature. Instead, informal businesses are disaggregated into micro-enterprises, survivalist enterprises and sub-sectors and a prescriptive package of predominantly supply-side interventions for the business - ranging from microcredit, skills and business training to marketing information - are routinely suggested in various different guises.

This article will challenge the dominant SMME paradigm that focuses on the business rather than the person who runs the business. I will argue for a different paradigm, "Sustainable Livelihoods" (SL), that allows us to make sense of chronically poor people's livelihood strategies in the context of their lives as a whole, rather than conceiving of livelihood strategies as a "business" that requires business interventions to grow. An SL lens would allow us to consider how both business and non-business interventions could impact on livelihood strategies.

Section one of the article describes the informal economy in South Africa. It disaggregates informal businesses according to their scale and sector and sketches a profile of the typical owner of an informal business.

Sections two and three outline and critique South Africa's SMME policy framework from the perspective of informal business. I argue that the current paradigm, with its market-based tools and envisaged market outcomes, reflects a narrow view of development which pays insufficient attention to the need to level the playing field and holds little promise of eradicating the "unfreedom" of "poor economic opportunity" of those who are marginalised. Moreover, this paradigm shifts the responsibility to the most marginalised to "self-employ themselves out of poverty"12 under the guise of agency.

Section four proposes a different analytical lens and argues for a revisioning of the paradigm to support informal enterprises. I argue that a framework such as SL

\footnotetext{
${ }^{11}$ Andries du Toit and David Neves "In search of South Africa's second economy: Chronic poverty, vulnerability and adverse incorporation in Mt. Frere and Khayelitsha" (unpublished paper presented at Living on the Margins Conference hosted by PLAAS and the Chronic Poverty Centre, Stellenbosch, 2007) at 6.

12 Kate Philip "How the structure of the economy impacts on opportunities on the margins": Paper prepared for workshop "Working on the Margins: Addressing structural poverty and exclusion in South Africa" (Cape Town, 25-27 March 2009) at 5.
} 
acknowledges the structural barriers to equal participation in the economy. It is rooted in the reality of how chronically poor people engage in making a living, which facilitates more appropriate, effective responses to informal businesses than the current SMME strategy. It also holds the possibility of real agency by chronically poor households.

I conclude with an exploration of the policy implications of such a lens. The most radical implication is that informal economy support would no longer be the domain of one ministry but form part of the South African government's broader development strategy.

Global development agencies such as the Swedish International Development Cooperation Agency (SIDA), the (UK) Department for International Development (DFID), the Cooperative for Assistance and Relief Everywhere (CARE), the United Nations Development Programme (UNDP) and Oxfam use SL as a poverty alleviation framework. CARE and the UNDP employ it as a poverty reduction strategy in that they use it "to facilitate the planning of concrete projects and programmes". ${ }^{13}$ DFID, by contrast, uses it only as an analytical tool or lens. ${ }^{14}$ This article argues for SL to be used as an analytical tool, as a lens that helps us to frame the questions or issues differently and therefore to imagine alternative policy responses to the question of increasing the income generation possibilities of chronically poor people. The article therefore does not prescribe how such analysis should translate into policy or strategy. ${ }^{15}$

\section{A PROFILE OF INFORMAL BUSINESSES AND THEIR OWNERS}

Since the term "informal sector" was first coined in 1973 by Keith Hart it has been the subject of extensive deliberation. The ILO's definition, a point of reference for subsequent debate, describes the informal sector as businesses characterised by seven specific traits, including low barriers to entry, small-scale operations, being labour intensive, family owned, reliant on skills acquired outside of formal schooling and operating in unregulated and competitive markets.

For the purposes of this article, informal businesses are defined as unregistered, unregulated economic activities that contribute to the gross domestic product. The term "informal economy" includes businesses, casual and contract workers, domestic workers and farm workers. Just over a third of the population in the

\footnotetext{
${ }^{13}$ Lasse Krantz "The Sustainable livelihoods approach to poverty reduction" (SIDA, Division for Socio-Economic and Policy analysis, 2001) at 3.

${ }_{14}$ Jane Clark and Diana Carney "Sustainable Livelihoods Approaches - What have we learnt: A Review of DFID's Experience with Sustainable Livelihoods" (ESRC Research Seminar, October 2008).
} 
informal economy own and manage a business. ${ }^{16}$ A small percentage of the remaining two thirds are employees - mostly unpaid - of these businesses.

Estimates of the size and contribution of informal businesses to the GDP vary considerably. It is estimated that there are between 1 and 2.3 million informal businesses in South Africa, which contribute between 7 and 12 percent to South Africa's GDP. ${ }^{17}$ Micro-level studies - seven in total - suggest that between 3 and 7 out of every ten households in informal settlements engage in some kind of informal income generation activity. ${ }^{18}$ An estimated 45, 5\% of informal enterprises are owned and managed by women. An estimated 91,3\% are owned and managed by Africans. ${ }^{19}$ It is self-evident that the informal sector is not homogenous, with differences in scale, sector and the profile of owners.

\subsection{The scale of the business}

Early papers ${ }^{20}$ that predate the White Paper on the Development and Promotion of Small Business in South Africa ${ }^{21}$ grappled with the fact that some informal businesses constitute little more than survival strategies whereas others seem to have the potential to grow into something more sustainable. Terms such as "survivalist", "emerging" and "expansionist" emerged. Survivalist businesses are subsistence businesses where the owner is generating an income while employment in the formal sector is not available. Expansionist or emerging businesses are those where the owner is displaying entrepreneurial qualities. ${ }^{22}$

Academics refer to "strategies of maximisation" and "strategies of desperation"23 or "push" and "pull" factors ${ }^{24}$ or "necessity" and "opportunity" businesses, ${ }^{25}$

16 Imraan Valodia "Economic Policy and Women's Informal and Flexible Work in South Africa" Development and Change, vol 32, Number 5, (Nov 2001) 871-892.

17 Dewar "A Conceptual Framework for the Formulation of an Informal Trader Policy for South African Towns and Cities" Urban Forum vol 16 no 1 (2005).

18 Valodia (2000); Napier et al (2002); Lithelm (2005).

19 Statistics SA 2005. I use the most recent "official" statistics reported by Statistics SA in its Survey of Employers and the Self-Employed (SESE) rather than the Labour Force Survey from which we can only extrapolate informal business statistics, given that it is a population survey. The latest 2005 SESE was released in November 2006. SESE defines informal businesses as those not registered for value-added-tax (VAT).

${ }^{20}$ Such as Taskgro(1993); Riley (1993); Ruiters et al (1994).

${ }^{21}$ White Paper on National Strategy for the Development and Promotion of Small Business in South Africa (February 1995).

${ }^{22}$ A Ruiters, A China and S Spicer "The functioning of micro enterprises and support services in the Western Cape" (unpublished paper prepared for CASE, Cape Town, 1994) at.139.

${ }^{23}$ Cross and Preston Whyte (1983) in M Napier and M Mothwa "Push and pull factors in the initiation and maintenance of home work in two Pretoria settlements: the myths and realities of South African home-based enterprises" Urban Forum, vol. 12 no. 3 (2001).

${ }^{24} \mathrm{M}$ Napier et al, op cit. 
thereby emphasising the primary impetus for starting the business, namely whether the business owner was "pushed" into it for reasons of "survival", "necessity" or "desperation", or whether he or she started the business in response to, or was "pulled" by, an "opportunity" that describes a "strategy of maximisation".

Later papers and initial government policy documents merely reflect a distinction between survivalist and micro-enterprises. At a policy level the two have most often been conflated. The National Small Business Act of 1996 appears to classify micro and survivalist businesses as a single grouping and the level of strategy they are treated as a single constituency by the Small Enterprise Development Agency (SEDA), ${ }^{26}$ the national organisation responsible for facilitating nonfinancial support to SMMEs. Similarly, the Department of Trade and Industry (DTI)'s Integrated Small Enterprise Development Strategy 2005-14 does not differentiate between survivalist and micro-enterprises.

From a policy point of view the distinction is only of relevance if micro-enterprises, unlike survivalist enterprises, have the potential to grow into viable enterprises that generate sustainable and socially desirable levels of earnings for the employer and employees. But data seem to indicate micro-enterprises differ little from survivalists. As noted by Kesper,

"Wage and working conditions in emerging micro-enterprises are reported to be uniformly poor both for owners and their employees, which places at least a question mark at the sustainability and quality of the employment generated. " 27

Figure 1 (on next page), based on the 2001-2005 Labour Force Surveys, shows the monthly earnings of both owners and employees. ${ }^{28}$ Ninety two per cent of owners and employees of informal businesses earn below R 2500 a month. A significant 71 per cent earn below R 1000 per month. The 11 per cent that do not earn anything most likely refers to family members who work in micro-enterprises as unpaid employees. It is estimated that only 3 per cent of the employees of informal businesses are paid.

As only 8\% of employers and employees earn above R2 500 per month, of which a significant proportion is likely to earn closer to R2 500 than R8 000, this distinction between survivalist and micro-enterprises masks the fact that the vast majority, in excess of $92 \%$, is chronically poor and face the same structural barriers to growing their businesses. In the remainder of the article I therefore refrain from distinguishing between survivalist and micro-enterprises and refer instead to informal businesses.

25 Annual Global Entrepreneurship Monitor, Graduate School of Business, University of Cape Town. 26 Formerly known as Ntsika Enterprise Promotion Agency.

27 A Kesper "Failing or not aiming to grow? Manufacturing SMMEs and their contribution to employment growth in South Africa" TIPS Working Paper 15 (2000) at 8.

28 These figures exclude earnings from other sources, such as remittances from wage earners, and welfare transfers, namely childcare grants, pensions and disability grants. 
Figure 1: Monthly earnings of survivalist and micro-enterprises

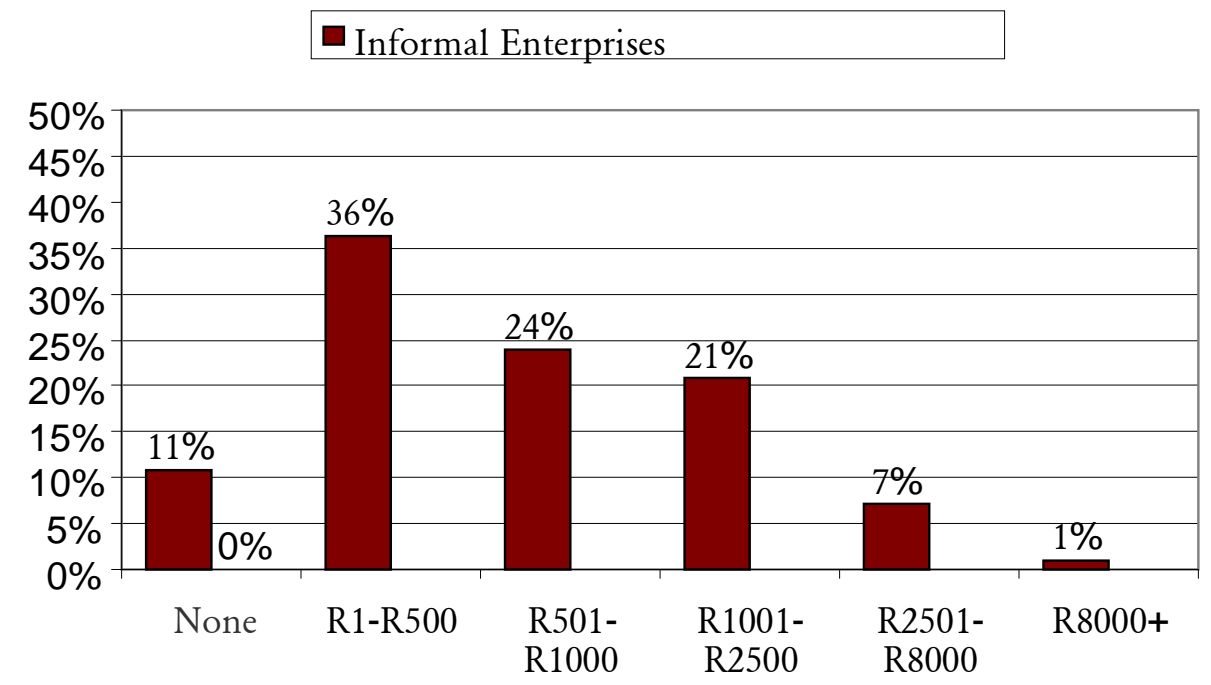

Source: Skinner (2007); calculations based on Labour Force Survey

\subsection{Distribution of informal businesses by sector}

Only a small minority of informal businesses are able to access formal markets. ${ }^{29}$ The vast majority sell their goods and services to a poor, local, overtraded market. They trade in low value-added activities, profit margins are small and competition is fierce. ${ }^{30}$ The potential of a business to access the formal (more differentiated and lucrative) market is largely determined by the sector in which it operates. As reflected in Figure 2, more than half of informal businesses are in the retail sector. Typically these businesses include spaza shops, shebeens and second-hand furniture shops as well as sweet, meat and fruit selling. Retailers include street traders who sell their goods from pavements or stalls in urban centres. Approximately $9 \%$ of informal businesses are located in the service sector, ${ }^{31}$ typically including hairdressers, phone booths, car repairs, hiring companies and radio and television repair. Though larger businesses operate from business

\footnotetext{
${ }^{29} \mathrm{M}$ Napier and M and S Liebermann "Investigation into entrepreneurs and small scale landlords": Unpublished paper prepared for Shisaka Development Services in Association with the CSIR (2006). Street Traders often access "formal" markets and thus have to comply with formalities, even if many operate at survivalist levels. Street traders constitute a specialist area and fall beyond the scope of this paper, which primarily addresses home-based businesses.

30 Rogerson (1997) refers to eight articles that support this finding. Also see Ruiters et al (2004) at 148; Kesper (2000); Rogerson (2002); Tipple (2005); Berry et al (2002) and Napier \& Mothwa (2001).

31 C Skinner "Laws Governing Street Trading in South Africa": Unpublished input paper produced for the Commission on Legal Empowerment for the Poor (2007).
} 
premises or hives in black metropolitan areas, the majority operate from homes or tables at transport nodes.

Street traders, construction and agricultural businesses, and businesses involved in the mining, quarrying or transport sectors seldom trade from business premises in black metropolitan areas or from homes and require compliance with legislation specific to the respective industries. They are not the focus of this article.

Figure 2: Distribution by sector

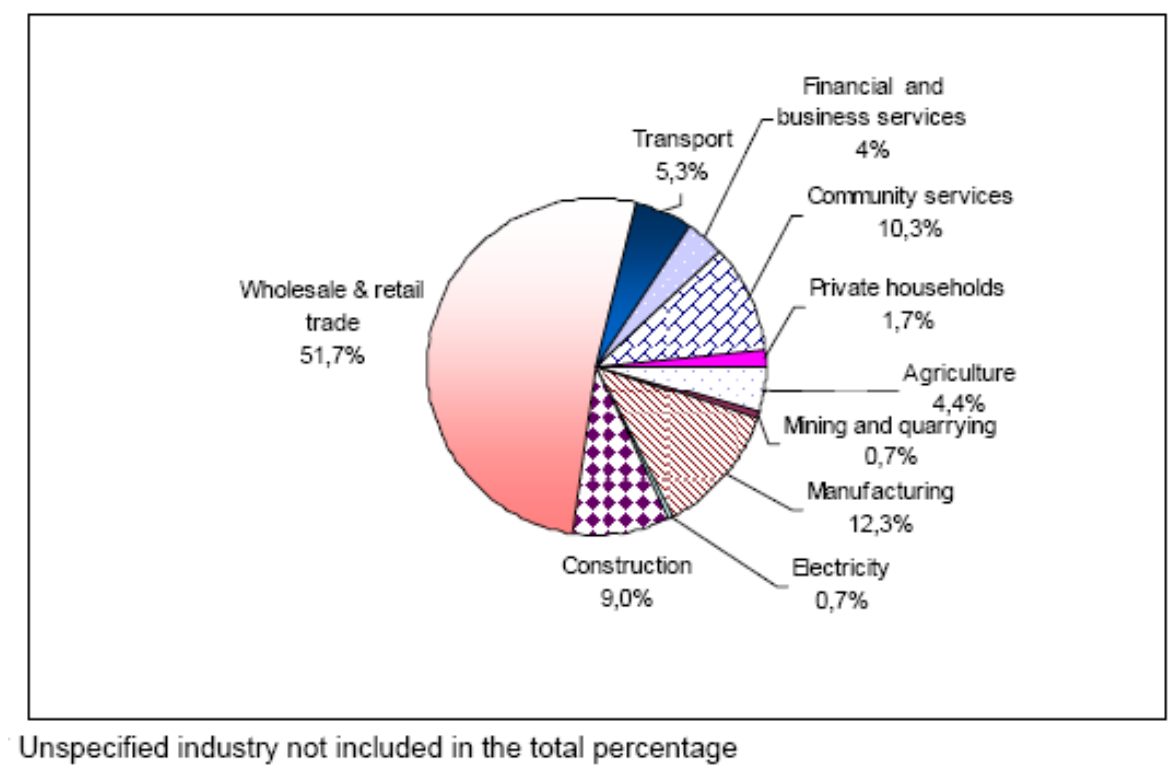

Source: Statistics SA (2005) xv.

The vast majority of the approximately $12 \%$ that are manufacturing enterprises are engaged in manufacturing "soft" goods such as dressmaking or in shoerepairing and beer brewing. "Hard" manufacturing, such as wood and wood processing, printing and publishing, paper, chemicals and plastics, are unusual. Only a small percentage of informal businesses in the craft, agricultural, construction, textile and tourist sectors can potentially create forward linkages with the formal sector, and then only, almost without exception, if mediated by an intermediary that lowers the barriers to entry.

The barriers are multiple. The Cape Craft Design Institute (CCDI), an intermediary in the craft sector, argues that even if informal producers could overcome their lack of technical skills, information, finance, storage space and transport and the effects of crime, producers would still not be able to access sophisticated external 
markets where "design is key, quality and consistency is vital and trends shift rapidly." 32

The subject of intermediaries is complex and cannot be dealt with fully in this paper. ${ }^{33}$ However, Raynolds, who writes on fair trade in the coffee industry, highlights an issue that is germane to this discussion. He argues that despite the intention (of fair trade) to reach "marginal populations", "marginality may militate against successful participation." 34 The producers' level of education, market sophistication and access to capital and other resources determine how successfully they can maintain the relationship with the intermediary, given the high standards required by the European market. Language, literacy and education are significant indicators of success. If the intermediary is a membership-based organisation (like a co-operative), it invariably tends to rely on a few coffee growers that exhibit the requisite skills or tends to hire non-members to ensure that it can fulfil the stringent requirements of the market.

Given the focus of this article on chronic poverty, any strategy to support informal business would have to be premised on a realistic assessment of the language, literacy, levels of education and access to capital of those targeted for support. I briefly discuss these issues below.

\subsection{The profile of the owners of informal businesses}

Studies concur that the owners of the majority of informal businesses are poorly educated. Many are illiterate and cannot speak English, which is a prerequisite to access markets outside of the local community. The majority have no formal sector employment history and are formally unskilled. The prospects of current learners at school are little better. The systemic nature of South Africa's poor education at school is ascribed to poorly-qualified teachers, large pupil to teacher ratios, the inability of teachers to teach new curricula and poor management of schools. ${ }^{35}$

The owner of a typical informal business has limited access to resources. He or she lives in a shack or a $23-30 \mathrm{~m} 2$ brick house. If she lives in a shack, she has no title to her home. If she lives in a brick house, she has title but the poor quality of government housing and neighbourhood crime mean that there is no established

\footnotetext{
32 This extract is from a power-point presentation by CCDI which does not cite an author or a year. These views were echoed in an interview with Anne Weyer of CCDI in August 2007.

${ }^{33}$ CCDI, for example, mediates by providing producers with information about the market and design input, consolidating volumes from small producers, securing large export orders and dividing them between small producers, and assuming financial risk.

34 A Raynolds "Poverty alleviation through participation in fair trade coffee networks: existing research and critical issues": Background paper prepared for The Community and Resource Development Program, The Ford Foundation, New York (March 2002) at 15.

35 Orford et al (2004); Kingdon (2002); Van den Berg (2005).
} 
second-hand market. Banks are accordingly reluctant to accept these homes as collateral for loans. Access to banking facilities is limited to a savings account. Typically, owners rely on informal savings mechanisms such an informal rotating credit fund based on reciprocity.

While women own less than half of informal businesses, they dominate marginal livelihood activities. Women are at home and care for children, but the opportunity costs of child-care and household responsibilities impact heavily on income generation. A qualitative study by Nqelo and Malan captures this well:

"Women at home do household chores first before they switch to working on their businesses. These chores could take up half of their day. Being at home in African areas, especially in areas where most people are unemployed, often means attending to visitors or passers-by as it is rude to chase people away. Sadly therefore the business suffers." 36

As I argue in succeeding sections, an approach that focuses only on the business and ignores the socio-economic context - such as the implications of the limited skill set of business owners, the implications of gender roles and the marginalisation that results from being located in townships far from formal markets - is unlikely to contribute to the growth of informal businesses and their meaningful participation in the economy.

\section{THE POLICY FRAMEWORK}

In 1995 the Department of Trade and Industry (DTI), the government department tasked with overhauling the approach to small business, published its White Paper called "National Strategy for the Development and Promotion of Small Business in South Africa". The White Paper was groundbreaking in that the new democratically elected government articulated a comprehensive strategy for the support of SMMEs for the first time which, it was widely held, reflected best practice.

The primary objective of the National Small Business Strategy (NSBS) was to create an "enabling environment" for SMMEs. Specific objectives of the strategy were to (a) facilitate greater equalisation of income, wealth and economic opportunities; (b) create long-term jobs; (c) stimulate economic growth; (d) strengthen the cohesion among small enterprises; and (e) level the playing fields between big and small business.

The absence of poverty alleviation as a specific objective is noticeable. In keeping with terminology reflected in literature in South Africa, the White Paper categorised poor people's marginal informal economic activities as "survivalist enterprises", which are described as

${ }^{36}$ Nomonde Nqelo and Liesl Malan "Comparative Study for Impact Assessment and Course Design" unpublished paper prepared for The Triple Trust Organisation, Cape Town, 1998, p36. 
"activities by people unable to find a paid job or get into an economic sector of their choice. Income generated from these activities usually falls far short of an even minimum income standard, with little capital invested, virtually no skills training in the particular field and only limited opportunities for growth into a viable business. Poverty and the attempt to survive are the main characteristics of this category of enterprise." 37

Accordingly, the White Paper argues that the appropriate strategy in respect of "survivalists" would be to assist them to leave the survivalist sector by improving their literacy and skills for employment, as opposed to self-employment.

Informal businesses that were included in the SMME strategy, termed "microenterprises", were defined later. The distinguishing features of a micro-enterprise were related to turnover, informality and the number of employees. The turnover should be less than the VAT registration limit (then R300 000 per annum); it should be characterised by a lack of formality (i.e., not being registered for purposes of tax, unemployment insurance or compensation for occupational injuries and diseases; and premises and accounting procedures should be "informal". Lastly, micro-enterprises should employ between one and five people. ${ }^{38}$

The White Paper stipulated that government's role in the SMME support strategy would be one of facilitation, rather than of implementation, which is defined as follows:

- taking responsibility for creating an enabling legal framework and streamlining regulatory conditions; i.e., providing an enabling context within which SMME development can flourish;

- facilitating access to information and advice; markets, procurement opportunities and raw materials; finance; physical infrastructure, including business and industrial premises, electricity, water, telecommunication connections, sewage, street lights, and parking; training in entrepreneurship, skills and management; and appropriate technology;

- encouraging joint ventures; and

- facilitating capacity-building and institutional strengthening of small business associations.

The implementation of the NSBS relies on a partnership between the three tiers of government, non-governmental organisations, parastatals, community-based organisations, business associations, the private sector and foreign donor agencies. Two national institutions were created: Khula, to facilitate SMMEs' access to

\footnotetext{
${ }^{37}$ Department of Trade and Industry National Strategy for the Development and Promotion of Small Business in South Africa (February 1995) at 10.

${ }^{38}$ National Small Business Act 102 of 1996.
} 
finance, and Ntsika (renamed SEDA) to facilitate SMMEs' access to non-financial areas of SMME support. While a range of players were active in the SMME support sector, the primary implementers were NGOs. This perhaps explains why it was found that "the [National Small Business] strategy's programmes are heavily geared towards the micro-enterprise/survivalist category"; ${ }^{39}$ in other words, to informal business, the client base of NGOs.

Since 2000 the notion that, with the right business inputs, survivalist enterprises will grow into micro- and small enterprises, reswulting in increased income of the owner and providing jobs for others, has been implicit in government programmes and strategy and explicitly articulated in policy documents:

"In terms of economic development, SMMEs play a crucial role. They enable people to meet their basic needs and survive. Through the growth of the SMME sector, survivalist enterprises can become micro and small enterprises, creating jobs and raising the standards of living for hundreds of thousands and even millions of South Africans in urban and rural areas" (my italics).40

It would seem that government's informal economy strategy is in pursuance of its "economic development" objective. DTI's Integrated Small-Enterprise Development Strategy echoes the view that survivalist and micro-businesses will, with "the necessary linkages in the continuum of enterprises, graduate from local micro to globally competitive businesses". ${ }^{41}$

This seemingly logical progression from survivalist to micro- to small enterprise lies at the heart of the NSBS's strategy to assist informal businesses. This article will argue, first, there is no empirical evidence supporting the view that, with the right inputs and by correcting market failure, a significant percentage of informal enterprises will graduate along the business continuum. Second, the government's paradigm ignores structural barriers to growth; third, it has been crafted with little reference to the complex reality in which those who are economically marginalised generate livelihoods; and last, as Philip ${ }^{42}$ argues, this strategy shifts responsibility to poor people to "self-employ themselves out of poverty". The strategy thus amounts to formal rather than the substantive equality that is envisaged by our Constitution.

\footnotetext{
39 Carana Corporation "Mid-Term Review of the National Strategy for Small Business Development and Promotion in South Africa": Report for the Department of Trade and Industry (1999) at 6.

40 Department of Trade and Industry The State of Small Business in South Africa: prepared by the Policy, Research and Information Division of Ntsika (2001) at 38.

41 See preface to Department of Trade and Industry "Integrated Strategy on the Promotion of Entrepreneurship and Small Enterprises" (2005) at http://www.thedti.gov.za/smme/strategy.pdf. (accessed 14 November 2010). Also see Aliber "Synthesis Report of the 2005 Development. Report: Overcoming Development in South Africa's Second Economy" (2005) at 5, accessed on 23 November 2000 at http://www.sahrc.org.za/sahrc cms/downloads/6th\%20ESR\%20report.pdf.
}

42 K.Philip. op cit, p.16. 
The following sections critique the current SMME paradigm from the perspective of those who are chronically poor and propose a different lens, namely Sustainable Livelihoods (SL), discussed more fully in section 5 below.

\section{A CRITIQUE OF SOUTH AFRICA's SMME PARADIGM}

In 1990, Wolmarans used the metaphor of "the entrepreneurial ladder" to illustrate that formal and informal businesses form part of the same continuum. With the right inputs, Wolmarans argued, businesses can climb the entrepreneurial ladder. Early SMME papers unquestioningly adopted this metaphor, accepting the premise that, with the right supply-side inputs such as training and micro-credit, informal businesses could graduate to become small formal enterprises. ${ }^{43}$

These early papers influenced the intellectual framework of informal sector discourse in two ways. First, the focus is the business (or business sub-sector) rather than the "owner" of the business as part of a household. In effect, one activity of the household - namely, a single livelihood strategy - is isolated from other household activities. Second, the notion that formal and informal businesses form part of the same continuum is widely reflected in SMME discourse. ${ }^{44}$ Dewar articulates this view as follows:

It is misleading, from a policy perspective, to separate artificially informal, small-scale activities from larger, more formal ones. They do not operate in different economic circuits: indeed, they are inextricably interrelated, often with complex economic linkages. They also have similar economic requirements and respond to similar stimuli, although the form of the responses may differ. From a policy perspective, therefore, the term " informal sector" simply focuses attention on economic enterprises at the bottom-end of a continuum, ranging from very large to very small (micro and survivalist) enterprises.... It is clearly not the role of policy to assist those traders who are doing well to do even better. The focus of policy should be on independent survivalist and micro-enterprises. 45

If, as Dewar argues, the focus of SMME policy should be on informal businesses, the question is in pursuance of which policy objective: economic growth, redistribution or job creation?

If the aim is job creation, there is a dearth of empirical evidence to support the view that survivalist and micro-enterprises will create jobs at socially acceptable levels. To the contrary, several studies show that informal businesses do not

\footnotetext{
${ }^{43}$ Hirshowitz et al (1994); Tasgro (1993).

44 See Napier et al 2006; Devey et al 2006 and Dewar 2005.

45 Dewar, op cit p.33. These arguments challenge the dualism that Mbeki's " first/second economy" was thought to introduce.
} 
provide significant employment and are unlikely to do so in the future. ${ }^{46}$ If the objective is redistribution, will the market tools that are the primary interventions of the current SMME strategy effect meaningful redistribution? If economic growth is the goal, do informal businesses increase their turnover and graduate along the continuum with the interventions implicit in the current market-based SMME paradigm?

While few people dispute the fact that there are linkages between informal and formal business, linkages in and of themselves do not imply growth in a business, either in turnover or in the creation of employment. Although informal businesses have a multiplicity of linkages with the formal sector, for the vast majority these are backward linkages in the form of sourcing supplies and services from formal businesses. ${ }^{47}$ Forward linkages - the sale of goods and services to a formal market - are limited to specific sectors and, even then, mostly rely on intermediaries to mediate the relationship.

There has been little systematic evidence of the incidence of micro-enterprise "graduation" or growth into larger ones in Africa. Indeed, one-person operations constitute the majority of small-scale industry in Africa, of which only about $1 \%$ succeed in "graduating" to an intermediate size. ${ }^{48}$ Corporate subcontracting to small and mostly "informal" firms in Africa is more often than not a means to reduce costs by exploiting labour-surplus conditions and circumventing regulations and trade union organisation. ${ }^{49}$

The national network of NGOs created in the late 1990s to facilitate linkages between formal and informal businesses has collapse. The model that envisaged formal businesses subcontracting non-core activities to informal business proved to be too ambitious ${ }^{50}$. John James, Director of the USAID Southern African Linkage Programme and South African Business Linkage Programme (SABLE), argues that the high transaction costs incurred by formal business in transacting with large numbers of small contractors are not sustainable, thus leading to the demise of the model as a policy objective. Government's own preferential procurement programme has involved contracts with formal, not informal, black-owned businesses. ${ }^{51}$

\footnotetext{
46 See Kesper (2000); Qualmann (2000), Berry et al (2002), Haines \& Wood (2005) and Von Broembsen \& Wood (2005).

47 Interventions in backward linkages to reduce transaction costs are vital. The Triple Trust Organisation has created a membership-based entity for spaza-owners which negotiates with wholesalers. Profit margins of members have increased as a result: see Von Broembsen (2008).

${ }^{48}$ Kesper (2000) cites five studies to support this view.

49 Ibid at 4.

50 Interview with the Acting MD of the Business Opportunities Network (BON), 2007.

51 Interview with John James, September 2007.
} 
Market interventions such as provision of credit, infrastructure and business training may increase profit margins, but the business may remain constrained for example, by the lack of education and formal sector work experience of the "owner" - to operate in the same local markets. In other words, the business does not climb the ladder to the next level. ${ }^{52}$

The Development Bank's study, "Overcoming Underdevelopment in South Africa's Second Economy", found that "one of the key constraints on small business - and in particular on small business towards the micro- end of the scale - appears to be lack of effective demand for the products and services they sell". ${ }^{53}$

\subsection{The current paradigm fails to recognise structural constraints}

The Trade Industrial Policy Strategy (TIPS) think-tank acknowledges in its "Second Economy Strategy Framework" that the market- based SMME paradigm has largely failed to impact those who are chronically poor:
"Many second economy programmes are designed to achieve impacts that are measured as market-based outcomes - by creating more jobs, better jobs, more micro- enterprises or better returns to entrepreneurs, for example. While government plays a crucial role in shaping markets, its ability to impact on market outcomes is nevertheless largely indirect .... So far, government has not had great success where outcomes depend on a market response, particularly in marginal economic contexts. ${ }^{54 "}$

The toolkit of a market-based paradigm is limited to market interventions and the paradigm privileges market over social outcomes. Market interventions typically include supply-side interventions, such as micro-credit and business and skills training, or interventions to correct market failure,as espoused by the recent Making Markets Work for the Poor (M4P) paradigm. M4P strategies typically include value chain analysis and strategies to facilitate more effective participation of informal businesses in value chains. While M4P has value, the approach privileges those in the few sectors that can to some extent participate in value chains ${ }^{55}$ but has little to offer (besides reducing transaction costs in backward linkages) those who are chronically poor, who engage in marginal economic

\footnotetext{
52 Many profitable informal business choose to remain informal for economic or livelihood reasons. The policy emphasis on seeking to "migrate" micro-enterprises from the informal to the formal sector, on the assumption that formalisation is a measure of business success, is questionable. From a business (as opposed to revenue) growth perspective, increase in turnover and employment rather than formality are perhaps more reliable measures of success.

53 Aliber Synthesis Report of the 2005 Development. Report: Overcoming Development in South Africa's Second Economy (2005) at www.sahrc.org.za/sahrc cms/downloads/6th\%20ESR\%20report.pdf.

54 TIPS op cit at 3.

55 See K Philip, footnote 7, for a critique of the "value chain strategy" for South Africa.
} 
activities, mostly in the retail sector, and who constitute the majority of informal businesses.

TIPS attributes the irrelevance of "market-based programmes" to "marginal economic contexts" to two factors. First, the unequal structure of the economy and "other forms of structural inequality", such as spatial inequality and unequal access to education, constitute structural barriers to informal businesses participating in the formal economy (other than through backward linkages or, as is the case in limited sectors, mediated by intermediaries). Philip enlarges on this point, arguing that the economy is highly centralised, capital-intensive and dominated by monopolies. ${ }^{56}$

Second, "programmes that aim to impact on market outcomes too often miss the mark; they sometimes even cause unintended negative consequences that deepen market failures rather than supporting the kind of market development or market change processes intended". ${ }^{57}$ Perhaps this is because a market-based paradigm ignores the complexity of the context within which chronically poor people generate their livelihoods, a point which I explore more fully below.

\subsection{The paradigm fails to take cognisance of complex reality}

As Du Toit and Neves point out, "the intellectual frameworks that are suitable for understanding micro-enterprises have little traction on the realities facing those in the so-called survivalist sector". ${ }^{58}$ A market-based SMME paradigm fails in several ways to acknowledge the complex reality of how chronically poor people generate incomes.

First, owners of informal businesses do not differentiate between home and business consumption and expenditure. ${ }^{59}$ The focus on the "business" and the needs of the business is therefore artificial.

Second, the approach is not gender-sensitive. While approximately $45 \%$ of informal businesses are owned by women, women are concentrated in the least profitable businesses. Although more than $60 \%$ of survivalist enterprises are owned by women, the SMME strategy ignores the impact of household and

\footnotetext{
56 Philip, op cit at 5.

57 Trade Industrial Policy Strategies (TIPS). "Second Economy Strategy: Addressing Inequality and Economic Marginalisation". A Strategic Framework (January 2009) 3: available at http://www.tips.org.za/programme/2nd-economy-strategy-project. (accessed 14 November 2010).

${ }^{58}$ A du Toit and D Neves. Du Toit, A and Neves, D. "In search of South Africa's second economy: hronic poverty, vulnerability and adverse incorporation in Mt. Frere and Khayelitsha": prepared for the Living on the Margins Conference, hosted by PLAAS and the Chronic Poverty Centre, Stellenbosch (March 2007) at 24.

${ }^{59}$ Kew (2002); Tipple (2005); Du Toit and Neves (2007).
} 
childcare responsibilities on women's ability to generate income and the opportunity costs of their reproductive responsibilities. Consequently, the rather blunt market-based instruments to facilitate growth are often misguided in that they fail to address the barriers to growth for women's businesses or to address their needs. This point will be enlarged upon in the subsequent section.

Third, it fails to recognise that the social dynamics of each geographical context are different and that replicating a programme or an intervention that is successful in one area is often not appropriate in another, as it may fail to respond to local socioeconomic realities.

Finally, as Philip insightfully argues, a paradigm which insists that, despite the structural inequalities they have to navigate, chronically poor people must somehow be entrepreneurial enough to participate in the economy, amounts to shifting the responsibility to chronically poor communities to "self-employ themselves out of poverty". ${ }^{60}$

Perhaps, if early research had not conceived of income generation activities as "businesses" or the notion of the "entrepreneurial ladder" had been engaged with more critically, the intellectual framework in which support for livelihood activities is debated would be a very different one.

In one of the early SMME papers, Hirshowitz and Orkin ${ }^{61}$ assessed the availability of support services in three provinces and the extent to which the support organisations met the needs of the micro-enterprises. They found that the impact on micro-enterprises of general development organisations was greater than that of small enterprise support organisations. Interventions based on the reality of chronically poor people's lives in all their facets are more likely to address the real constraints to generating more income.

\section{TOWARDS A NEW PARADIGM FOR INFORMAL BUSINESS SUPPORT}

If income-generation strategies are conceived of not as a business issue but rather as a critical component of what Sen would call "well-being", this would have at least two implications. First, we would take cognisance of the economic, social and political structures that impact on people's lives as well as the physical and economic environment, as we know these have an impact on well-being. In the paradigm explicated below, this is referred to as the "vulnerability context". Second, we would attach importance to the poor's own perception of poverty and the priorities that they themselves identify. Women, for example, may identify

\footnotetext{
${ }^{60}$ Philip op cit at 5.

${ }^{61}$ Hirshowitz and Orkin "Micro-Enterprise Development in South Africa": Unpublished Paper by Community Agency for Social Enquiry (CASE) prepared for Kagiso Trust; GTZ, EU, ODA and DANIDA (1994).
} 
childcare as the intervention that would support their income generation strategies best, rather than business training.

Sen has developed the Capability Poverty Framework to give practical expression to his paradigm. His approach is mirrored in other frameworks, such as the Asset Vulnerability Framework and the one most used in practice, Sustainable Livelihoods (SL).

The SL framework, unlike South Africa's current SMME paradigm, focuses on what communities have, rather than what they need, which facilitates participation and agency. It captures the complexity of poverty and bridges the gap between microissues and macro or structural constraints. Its commitment to sustainability in financial, economic, social and environmental terms is more comprehensive than that of market paradigms, which emphasise economic and institutional sustainability.

The concept of SL was introduced by the Brundtland Commission on Environment and Development in 1983. In 1992 the UN Conference on Environment and Development further developed the concept and articulated the realisation of "sustainable livelihoods" as a global goal for poverty reduction. ${ }^{62}$ In the same year Chambers and Conway translated what was a conceptual idea into an operationalisable framework.

The most used definition of Sustainable Livelihoods is an adaptation of Chamber's and Conway's definition, namely:

"A livelihood comprises the capabilities, assets and activities required for a means of living. A livelihood is sustainable when it can cope with and recover from stresses and shocks and maintain and enhance its capabilities and assets both now and in the future, while not undermining the natural resource base."63

Capabilities comprise the skills and abilities that reside in the members of the household ${ }^{64}$ that enable the household to earn a living. These include production and entrepreneurial skills as well as personal skills and characteristics, such as the ability to locate and use resources, innovation and resilience and the ability to

\footnotetext{
62 Krantz op cit at 1.

${ }^{63}$ I Scoones "Sustainable Rural livelihoods: a framework for analysis" IDS Working Paper No 72 (1998) at 2.

${ }^{64} \mathrm{~A}$ commonly accepted definition of a household is that it is a socio-economic unit of one or more persons who may or may not be related but who live together and share food and shelter: UNDP (1999) at 23. The definition becomes more complex in the context of empirical research where researchers apply different criteria, e.g. with regard to the number of days per year someone must be "under the roof" to qualify as part of the household.
} 
plan. ${ }^{65}$ Key to the household's ability to generate income is the level of education and the health status of its members.

Assets refer to the resources that enable a household to generate an income. Literature identifies two types of assets: material and social. Material assets are tangible; that is, physical things that people own, control or have access to, including land, water, money, credit, livestock, farming equipment, tools, natural resources and infrastructure such as roads, electricity, water and sanitation. 66 Social assets, otherwise referred to as "social capital", are intangible and include benefits generated by social networks and reciprocal relationships between households in the community as well as between communities and institutions, including government.

Activities refer to the things that members of the household do in order to sustain the household and make a living. These activities include productive, reproductive and community maintenance activities. Productive activities refer to activities that produce income; reproductive activities refer to household and childcare responsibilities and community maintenance activities refer to the time and effort required to sustain reciprocal relationships within a community that are a resource (in the form of social capital or social assets) in times of crisis and drawn upon in the course of everyday life.

The analysis of capabilities, activities and assets is contextualised by an analysis of the "vulnerability context" or the external environment; that is, of institutional, political, socio-economic and physical (built and natural) factors at a local, national and global level that impact on the ability of households to make a living that is sustainable. ${ }^{67}$ Structural constraints to the growth of informal business would form part of the "vulnerability context".

A second useful lens is advocated by Caroline Moser68 in her work on gender. She differentiates between practical and strategic gender initiatives, the former referring to interventions that are identified by women themselves that will improve their lives, such as access to clean drinking water, literacy programmes and childcare, while the latter refer to initiatives which challenge gender relations.

This distinction would strengthen the SL framework. In the context of informal business, practical interventions would improve the livelihoods of particular

${ }^{65}$ R De Satge, A Holloway, D Mullin, I Nchabaleng and P Ward "Learning about Livelihoods: insights from Southern Africa": produced by Disaster Mitigation for Sustainable Livelihoods Programme (DiMP) at the University of Cape Town, Oxfam books, (May 2002) at 10.

${ }^{66}$ Ibid.

${ }^{67}$ Ibid.

${ }^{68}$ C Moser "Gender Planning in the Third World: Meeting Practical and Strategic Gender Needs". World Development, vol 17 No 11 (1989) 1799. 
groups of people in ways they identify themselves. Strategic interventions would challenge power relations, for example between formal sector suppliers and informal businesses, between male and female entrepreneurs, or gender relations in the household. Many strategic interventions would challenge the structural constraints that chronically poor people face when trying to grow their business.

Against this background I shall consider how the SL framework challenges the current approach to informal businesses and show that it could facilitate more appropriate and effective policy.

Figure 3: A visual Depiction of the Sustainable Livelihoods Framework ${ }^{69}$

\section{Vulnerability Context: Political, Economic, Legal Environment}

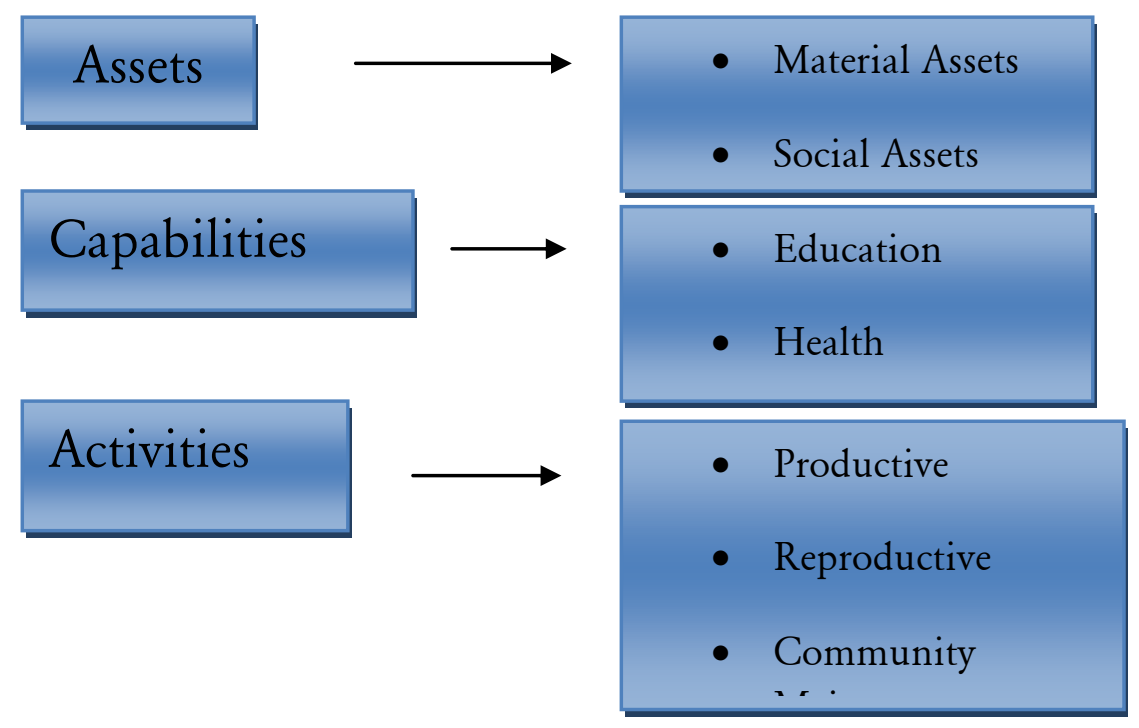

An analysis of the vulnerability context, the political, economic, legal and institutional framework, would include analysing the implications of the fact that, first, the formal market in South Africa is a sophisticated "first-world" market, which means the barriers to entry are considerable; and, secondly, government's industrial policy is premised on developing SMEs to be globally competitive (i.e., a capital-intensive rather than a labour-intensive growth path, which has implications for job creation). In addition, informal businesses are spatially

${ }^{69}$ Based on the SL framework articulated by De Satge et al (fn 65 above). 
separated from formal markets and from their suppliers, which increases transaction costs.

\subsection{Activities}

Inherent in an analysis of "activities" is a shift in focus from individual "owners of the business" to households, since the different activities - productive, reproductive and community maintenance - are typically allocated to different members of the household. Both men and women engage in productive activities, but women by and large assume responsibility for reproductive and community maintenance activities. Moser refers to women's "triple burden", which draws attention to the three roles women typically fill - that of producer, reproducer and maintaining reciprocal relationships. An analysis of the activities of households therefore introduces a gendered analysis, which portends very different policy responses.

The extent of the current SMME's gender strategy is to target woman-owned businesses for support. However, as women's needs are marginalised in households, ${ }^{70}$ even if they increase their productive activities, they continue to bear the burden of household chores, assisted only by children. In other words, women work a "double shift" (or as Moser would contend, a triple shift) to fulfil productive and reproductive responsibilities, which necessitates working for longer hours. ${ }^{71}$

Women's household and reproductive responsibilities impact upon their ability to generate income in several ways. First, the sundry demands on their time restrict women to sectors of the economy that allow for flexibility. Second, it restricts their mobility, which impacts on their ability to generate income: ${ }^{72}$

"[women feel] that having their children with them limit their ability to network, their access to training, and the frequency with which they are able to visit their suppliers." 73

As a result, female more than male entrepreneurs "suffer from atomistic competition and their enterprises are small and unspecialised." 74

Third, evidence from other developing countries suggests that women tend to engage in low-risk activities that guarantee basic consumption. Poor women tend

\footnotetext{
${ }^{70}$ M. Wittenberg "Conflictual intra-household allocations": Working Paper No 211, 2000, Princeton University, Woodrow Wilson School of Public and International Affairs, Research Programme in Development Studies at http://rdps.princeton.edu/rpds/papers/pdfs/wittenberg.pdf (accessed 3 October 2009).

${ }^{71}$ UNDP (1999); Tipple (2005).

72 Hilhorst \& Oppenoorth (1990); Nquelo \& Malan (1998); Taskgro (1993); Ruiters et al (1994); Rogerson (2002).

73 Ruiters et al at 147.

74 J. Downing "Gender and the Growth Dynamics of Micro-enterprises" Small Enterprise Development vol 2 no 1 (March 1991) 12.
} 
to prioritise stability and economic security over economic growth. ${ }^{75}$ As a result, women diversify their sources of income and "manage their diverse sources of income to maximise security (first food and material, then social) for their families and themselves". ${ }^{76}$ Mquelo and Malan's South African study suggests that the same holds true for South Africa:

"Women who are mothers and breadwinners 'feel far more pressure to earn good income than fathers.' Yet paradoxically, while their businesses do better, they welcome opportunities to receive income from another source, e.g., another job to the detriment of the business because the dual role of breadwinner and domestic work places such incredible pressure on them. .... African women assume the role of breadwinner reluctantly and lose motivation to run their business when they have an alternative way of providing an income. With Coloured interviewees we found that as women's perception of their gender roles changes, so do their orientation to business." 77

Research from other developing countries shows that, as a result, the growth pattern of enterprises owned and managed by women is horizontal rather than vertical. This means that women tend to employ investment capital to start new enterprises as opposed to increasing the size and productivity of an existing enterprise. ${ }^{78}$ It may be, therefore, that the intervention that would have the most impact would be to provide childcare or to change the perception of gender roles which, as reflected on in the above quote, would tackle some of the structural barriers for women.

Enterprise programmes such as the Grameen Bank and Bangladesh Rural Advancement Committee (BRAC) have adopted a very different model to that of South Africa. Inherent in their philosophy is a "bottom-up", consultative, participatory style. Organisations tend to target women, often exclusively. These organisations reflect a strong commitment to understanding the realities of their clients' lives and designing strategies that meet practical gender interests. For example, micro-credit programmes do not prescribe that loans must be used for the business (as in South Africa), just that loans are repaid. ${ }^{79}$ This acknowledges that the separation between business and household income and expenditure is artificial since it does not reflect the reality of how chronically poor people manage their lives.

South Africa's SMME paradigm targets women's businesses for support in isolation from other aspects of their lives. Thus strategies are formulated without regard to the triple role of women, the impact of these roles on the means by which livelihoods are secured or the practical needs of women. By contrast, the SL

\footnotetext{
${ }^{75}$ Hilhorst \& Oppenoorth (1992); Berger (1989).

${ }_{76}$ G Wright "Examining the impact of micro-finance services - increasing income or reducing poverty" Small Enterprise Development vol.10 No1 (March 1999) at 41.

77 Nquelo \& Malan at 36.

78 Ibid and Downing op cit.

79 Wright (1999).
} 
framework relies on a participative, bottom-up, non-sectoral approach that analyses income generation or livelihoods within a broader context. The result is practical strategies that increase women's incomes and encourage agency.

\subsection{Assets}

Assets are the resources that are used for gaining a livelihood, divided into social and material assets.

Social capital is so-named because it is a "non-market interaction of agents which nevertheless has economic effects ... that are not mediated by the market". ${ }^{80}$ Social assets or social capital at the micro-level ${ }^{81}$ refers to "intangible" assets, benefits or "externalities" (that can be positive or negative) that result from relationships with institutions such as networks, ${ }^{82}$ organisations, burial societies, stokvels and churches. These benefits accrue not only to the members of the organisation but to the community as a whole, as norms and values that are created by the network for example, solidarity and trust - have a multiplier effect.

It is useful to distinguish between structural social capital and cognitive social capital:

"Structural social capital facilitates information sharing, and collective action and decision-making through established roles, social networks and other social structures supplemented by rules, procedures, and precedents. As such, it is a relatively objective and externally observable construct. Cognitive social capital refers to shared norms, values, trust, attitudes, and beliefs. It is therefore a more subjective and intangible concept." 83

Literature on the implication of social capital for informal businesses abounds ${ }^{84}$ and there are examples in South Africa of structural social capital where the formation of a membership-based voluntary association of traders enables them to

80 P Collier "Social Capital and Poverty" Social Capital Initiative Working Paper No. 4 The World Bank, Social Development Family Environmentally and Socially Sustainable Development Network (1998) at 2.

81 The meso level considers relationships among groups as opposed to individuals and the macro level focuses on the "social and political environment that shapes social structure and enables norms to develop", which include the political regime and the rule of law - Collier, p.3.

82 Networks can be informal or formal. Informal social networks are face-to-face relationships.

83 C Grootaert"Social Capital: the missing link" Social Capital Initiative Working Paper 3 (April 1998) at http://siteresources.worldbank.org/INTSOCIALCAPITAL/Resources/Social-Capital-InitiativeWorking-Paper-Series/SCI-WPS-03.pdf. (accessed on 15 March 2009).

84 See, for example, the Social Capital Initiative of the World Bank: ibid. 
negotiate terms with wholesalers for members that they are unable to secure individually. ${ }^{85}$

Material assets are tangible assets. These are the physical things that people own, control or have access to which can be used to generate income. They include land, water, money, credit, livestock, farming equipment, tools, natural resources and infrastructure such as roads, electricity, water and sanitation. An SL approach would identify strategies to strengthen households' assets or their access to assets in order to facilitate a sustainable income.

Applying Moser's paradigm, policies would address both practical and strategic needs. Practical policies would focus on strengthening the assets and capabilities of the current generation of chronically poor, whereas the objective of strategic policy interventions would be to challenge the structural constraints that chronically poor people face when trying to generate income.

Businesses in townships that have more formal housing and access to electricity and running water are more sophisticated and sustainable than those where homes are "shacks" and have access to few amenities. ${ }^{86}$ While not using the language of SL, numerous studies show that improved housing, access to consumer credit, and even social security in the form of cash transfers, impact on the income generation ability of poor households. ${ }^{87}$

The Self-Employed Women's Association (SEWA) in India recognises the relationship between housing and income generation. SEWU, originally a trade union owned and managed by poor women in the informal sector, was started over 30 years ago in Gujarat. In 1973 the 4000 members formed a bank that provides micro-credit to illiterate self-employed women, now numbering over a million. SEWU argues that

" $[t]$ he dividing line between income generation loans and housing loans is often very blurred at the grassroots, due to the fact that inputs into a business such as water or electricity or paved flooring may be viewed as either a housing improvement or a business investment in order to increase productivity." 88

Almost half of these loans are for housing or infrastructure, such as adding a new room, "monsoon proofing", home maintenance, building a bathroom or paying for electricity or water connection. The organisation argues that "borrowing for home

85 For a detailed discussion on one such example, Shopnet (an organisation of spaza owners in the Western Cape), see Marlese von Broembsen, "SMMEs, the Informal Sector and the 'second Economy" PLAAS Working Paper No 10 (2009) at www.plaaas.org.za.

86 Napier \& Liebermann op cit.

87 Devereux (2000) and (2001); Wright (1999); Biswas (2003); Duflo (2000).

88 S Biswas "Housing as a Productive Asset: Housing finance for self- employed women in India" Small Enterprise Development vol 14 no1 (2003) at 54. 
improvements enables changes that can raise the earning capacity" of the home owners, most of whom operate their businesses from home. ${ }^{89}$

Over $60 \%$ of informal businesses in South Africa also operate from homes. ${ }^{90}$ Yet the primary support organisations for informal business limit their interventions to purely business-related interventions; this, despite the fact that South African studies suggest that the better the infrastructure, the more income is generated. As early as 1993 the Taskgro report commented - admittedly as an aside - that the work of organisations concerned with community upliftment had significantly more impact on informal businesses than the interventions of micro-enterprise support organisations. What this illustrates is that an SL lens would necessitate multi-sectoral strategies and a synergy of different Ministries' efforts to support chronically poor people's livelihood strategies. These would include, but not be limited to, business services such as business training and micro-finance.

\subsection{Capabilities}

Capabilities are defined as the mix of skills and abilities within a household which determine how, and how well, it secures a livelihood. Capabilities include the ability to work, which is determined by levels of education and health status; production and entrepreneurial skills; and soft skills such as management skills and the ability to plan and innovate.

A Harvard study illustrates empirically the impact of good health on the ability to work and the causal effect on national economic output. The article concludes that health is "a crucial aspect of human capital" ${ }^{11}$ South Africa's SMME paradigm pays attention to the acquisition of skills, such as business and technical skills that directly result in market outcomes, but not to health. Given the HIV/AIDS pandemic, it is of concern that studies that foreground the impact of HIV/AIDS on informal businesses are not in the public domain.

Education is also a key capability, both to secure employment and to start a viable business. Even effective participation in producer groups for fair trade markets is affected by the education of the participants. The more educated the person, the more likely they are to start a business in response to an opportunity rather than for reasons of survival. The business is also more likely to survive and to employ others. $^{92}$

89 Ibid. 51.

${ }^{90}$ Napier \& Liebenmann op cit.

91 D Bloom, D Canning and J Sevilla "The Effect of Health on Economic Growth: A production function effect" World Development vol 32 no 1 (2004) 1.

92 M Von Broembsen and E Wood Global Entrepreneurship Monitor: South African Executive Report Graduate School of Business, University of Cape Town (2005) at 28. 
Education cannot necessarily be equated with years of schooling. A study that analysed data from seven developing countries shows that, despite the fact that in Uganda and Brazil the proportion of adults that have not completed secondary schooling is higher than in South Africa, a significantly higher percentage are able to start sustainable businesses than is the case in South Africa. ${ }^{93}$ While the distribution of educational attainment is an enormous challenge in South Africa, the country is not unique. What does seem to differentiate South Africa from other developing countries is that the quality of education provided by schools is inferior.

SACMEQ II (Southern African Consortium for Monitoring Educational Quality) surveys show that South African schools perform poorly compared to schools in thirteen other African countries. Grade 6 learners, teachers and principals were surveyed in fourteen countries in southern and eastern Africa to assess reading and mathematical skills. SACMEQ categorises learners in terms of their socioeconomic status (SES) - the poor having a low SES and the wealthy having a high SES. Poor learners in South Africa are ranked eleventh in respect of both their reading and mathematics skills. In other words, of the fourteen African countries surveyed, only three are worse off than South Africa in terms of the quality of education provided to poor learners. ${ }^{94}$ These are countries with a significantly lower GDP per capita than South Africa

The poor quality education impacts on the kinds of businesses that poor people in South Africa are able to establish and in part explains why there is a bigger preponderance of manufacturing businesses in other developing countries, some of which are able to access formal markets, than in South Africa. ${ }^{95}$

Unless the problems of the education system in South Africa are addressed, one of the primary structural reasons for the inability of the chronically poor to find semiskilled or skilled employment in the formal sector or for informal businesses to access formal markets, thereby securing more sustainable livelihoods for themselves and potential employees, will remain in place for future generations.

\section{CONCLUSION}

This article has argued for a revisioning of the paradigm for support of informal businesses. It has argued that the current SMME paradigm, which separates the

\footnotetext{
93 Ibid at 40.

94 S van der Berg "The schooling solution: primary school performance is the key" in Susan Brown (ed) Economic Transformation Audit 2005: Conflict and Governance Institute for Justice and Reconciliation, Cape Town (2005).

95 M Napier and M Mothwa "Push and pull factors in the initiation and maintenance of home work in two Pretoria settlements: The myths and realities of South African home-based enterprises" Urban Forum vol. 12 no. 3 (2001).
} 
business from the household and community context, rests on an empirically untested assumption that, with the right inputs, informal businesses will prosper, graduate along the business continuum and ultimately participate in the "formal" economy through forward linkages. It fails to recognise that structural barriers for example, the structure of the economy, unequal access to quality education and spatial inequality - are, certainly for the most marginal livelihoods, not overcome by market interventions. Moreover, the paradigm fails to "fit" the reality within which chronically poor people generate income in at least three ways. First, it fails to take cognisance of the way that livelihood strategies are enmeshed with other activities of households. Second, livelihood activities constitute strategies to survive rather than being businesses. Finally, non-market interventions may have more impact on people's livelihoods.

South Africa's SMME paradigm espouses that government's role is to create an enabling environment; in other words, to create conditions that will enable previously marginalised entrepreneurs to participate more equally in the economy. As argued by an international pro-poor market development agency,

"[c]reating the conditions necessary for successful entrepreneurship enables the poor to take ownership of their livelihoods and harness the engine of private-sector growth for social returns. ... Supporting SME growth is an innovative way to eradicate poverty through the efforts of the poor themselves. Helping SMEs to surmount the barriers they face opens new avenues to poverty reduction." 96

This article has sought to show that it is fallacious to regard chronically poor people as entrepreneurs who, with some help, are able to surmount the barriers to economic participation and forge forward linkages with the formal economy. Therefore the discourse of "the poor taking ownership" really amounts to shifting responsibility to poor people for their economic marginalisation. As such it does not promote meaningful participation of chronically poor people in the economy or contribute to eradicating the "unfreedom" of "poor economic opportunity".

An SL lens would shift the focus from an analysis of the "business" to livelihood strategies within the context of household, communities and the broader socioeconomic context. The vulnerability context or external environment as well as poor people's own priorities are taken into account - in other words, both structural barriers to growth and the practical needs of poor people are integral to the framework. The framework would include non-market interventions that have market outcomes, such loans for housing or childcare. As the focus is on strengthening the assets and capabilities that households already have, there is potential for real agency. However, until the context is structurally more equal,

${ }_{96}$ CARE, Canada "Making markets work for the poor: CARE Canada's strategy for helping the poor through enterprise" (date unknown) at www.careinternational.org.uk/making-markets-work-forthe-poor-care-canadas-strategy-for-helping-the-poor-through-enterprise.html 4 (accessed 8 March 2009). 
this agency does not amount to poor people taking charge of their destiny. Rather, it constitutes practical strategies that improve their well-being.

All the activities of a household are considered, not just productive activities. Household and gender-focused research facilitates more nuanced, realistic policy responses to female "entrepreneurs". Appropriate policy responses need to be underpinned by analysis of disaggregated data that considers the differential transaction costs for men and women and the asymmetrical access of women to information, to rights such as property rights and, lastly, to bargaining power, at the level of the household and the broader community context.

Strengthening assets - both material and social - as well as capabilities, such as education, skills and health, increases the ability of chronically poor people to secure improved livelihoods. Education is critical to enabling informal business to access formal markets. Unequal education marginalises people and constitutes a structural constraint to escaping chronic poverty. Education (as opposed to schooling) is a significant determinant of the ability of the current generation of school learners to secure a better livelihood. ${ }^{97}$

Clearly, adopting an SL lens would have institutional implications. Arguably, the Inter-Departmental Committee on Entrepreneurship and Small Business Promotion, which co-ordinates different departmental strategies relating to SMMEs and operates within a market framework, is not the appropriate institution to develop policy in line with an SL paradigm. As Albu underlines, while proponents of market solutions and of SL approaches may have the objective of poverty alleviation in common, their values, assumptions and visions may be "relatively incongruent". 98

The key departments relevant to livelihoods - economic development, basic education, health, human settlements, and rural development and land reform are not all represented in any one of the newly configured clusters - human development, social development, community development or economic sectors and employment - that are relevant to livelihoods. A new cluster or interdepartmental committee themed on Livelihoods or the recently adopted "Second Economy Framework", which is synergistic with a SL paradigm, would be optimal.

97 Kingdon \& Knight (2000) and Lewis in DBSA (2005) argue that supply-side interventions such as education have limited potential to alleviate unemployment. But empirical studies such as the World Bank's “Constraints to Growth and Employment in South Africa” (Chandra et al 2001) show that growth of formal small businesses is hampered by a dearth of semi-skilled labour.

98 M Albu "Making Markets Work for Poor: International development co-operation: seeking common principles that underpin a coherent approach to poverty reduction" The Springlfield Centre UK (June 2008) 6 at http://www.springfieldcentre.com/publications/sp0803.pdf (accessed on 15 June 2009). 
In conclusion, market approaches, even when pro-poor, increase economic participation by a few but fail to address power relations, thereby excluding the most marginalised from participating in the economy and exercising agency. Such an approach, unmediated, reinforces existing inequalities. Market approaches do have a place but an SL paradigm has more relevance currently to the livelihoods of the majority of chronically poor people in our democracy. A Sustainable Livelihoods paradigm would birth policy responses that would expand people's freedoms and foreground the dignity of the most marginalised communities, as envisaged by our transformative Constitution. 


\section{BIBLIOGRAPHY}

Beattie, R. "Social protection for all: But how" (2000) 139 International Labour Review 129.

Benjamin, P. "An Accident of History: Who is (and who should be) an Employee under South African Labour Law" (2004) 25 ILJ 787.

Bosch, C. "Can Unauthorized Workers be regarded as Employees for the Purposes of the Labour Relations Act?" (2006) 27 ILJ 1342.

Braude, W. "South Africa: Bringing informal workers into the regulated sphere, overcoming Apartheid's legacy" in Avirgan et al (eds) Good Jobs, Bad Jobs, No Jobs: Labor Markets and Informal Work in Egypt, El Salvador, India, Russia and South Africa (Economic Policy Institute, 2005).

Albu, M. "Making Markets Work for Poor: International development co-operation: seeking common principles that underpin a coherent approach to poverty reduction". The Springlfield Centre, UK, June 2008, accessed on 15 June 2009, http://www.springfieldcentre.com/publications/sp0803.pdf.

Berger, M. "Giving women credit: the strengths and limitations of credit as a tool for alleviating poverty" (1989) 17(7) World Development 1017-1032.

Bertrand, M. Miller, D. and Mullainathan, S. Public Policy and Extended Families: evidence from South Africa. Mimeo, University of Chicago and M.I.T. (2000).

Biswas, S. "Housing as a Productive Asset: Housing finance for self- employed women in India" (2003) 14(1) Small Enterprise Development.

Bloom, D. Canning, D. and Sevilla, J. "The Effect of Health on Economic Growth: A production function effect" (2004) World Development 1-13.

Carana Corporation "Mid-Term Review of the National Strategy for Small Business Development and Promotion in South Africa" (Commissioned by The Department of Trade and Industry, 1999).

CARE, Canada "Making Markets Work for the Poor: CARE Canada's strategy for helping the Poor through Enterprise" ( 2004), viewed on 8 March 2009 at http://www.careinternational.org.uk/making-markets-work-for-the-poor-carecanadas-strategy-for-helping-the-poor-through-enterprise.ht.

Collier, P, "Social Capital and Poverty" (1998) Social Capital Initiative Working Paper No. 4 The World Bank, Social Development Family Environmentally and Socially Sustainable Development Network, viewed on 23 October at 2008 at http://siteresources.worldbank.org/INTSOCIALCAPITAL/Resources/SocialCapital-Initiative-Working-Paper-Series/SCI-WPS-03.pdf.

The Constitution of the Republic of South Africa, 1996. 
Department of Trade and Industr. The State of Small Business in South Africa: prepared by the Policy, Research and Information Division of Ntsika, ISBN 1919779-11-6, 2001.

The Department of Trade and Industry National Strategy for the Development and Promotion of Small Business in South Africa, White Paper February 1995, ISBN 0 621157953.

Department of Trade and Industry, Integrated Strategy on the Promotion of Entrepreneurship and Small Enterprises, 2005, viewed on 22 October 2008 at http//: www.thedti.gov.za/smme/strategy/pdf.

De Satge, R. Holloway, A. Mullins, D.Nchabaleng, L and Ward, P "Learning about Livelihoods: insights from Southern Africa" (2002) produced by Disaster Mitigation for Sustainable Livelihoods Programme (DiMP) at the University of Cape Town, Oxfam books.

Devereux, S, "Can Social safety nets reduce chronic poverty?" (Institute for Development Studies, 2001).

Devereux, S, "Social Pensions in Namibia and South Africa", (2001) IDS Discussion Paper 379.

Devereux, S "Social safety nets for poverty alleviation in Southern Africa"(2000) ESCOR Research Report, No R7017, London: Department for International Development.

Dewar, D "A Conceptual Framework for the Formulation of an Informal Trader Policy for South African Towns and Cities" (2005) 16(1) Urban Forum.

Downing, J. "Gender and the Growth Dynamics of Micro-enterprises" (1991) 2 (1) Small Enterprise Development 4-12.

Du Toit, A and Neves, D. "In search of South Africa's second economy: Chronic poverty, vulnerability and adverse incorporation in Mt. Frere and Khayelitsha" (Paper presented at Living on the Margins Conference, hosted by PLAAS and the Chronic Poverty Centre, Stellenbosch, 2007).

Finnegan, Gerard, 2003 “Facilitating Women's Entrepreneurship: lessons from ILO's research and support programmes" (International Labour Organisation, 2003).

Grootaert, C. "Social Capital: the missing link" ( 1998) Social Capital Initiative Working Paper 3, viewed on 15 March 2009 at http://siteresources.worldbank.org/INTSOCIALCAPITAL/Resources/SocialCapital-Initiative-Working-Paper-Series/SCI-WPS-03.pdf.

Haines, R and Wood, G. "Development Debate and Practice Unemployment, Marginalisation and survival in Greater East London" (2002) 19 (4) Development Southern Africa 473-581. 
Hilhorst, T and Oppenoorth, H. Financing Enterprise - beyond barriers and bias. London: IT Publications (1992).

Hirshowitz, and Orkin, M. "Micro-Enterprise Development in South Africa" (Unpublished Paper by Community Agency for Social Enquiry (CASE) prepared for Kagiso Trust; GTZ, EU, ODA and DANIDA, 1994).

International Organisation Development South Africa (IOD) "An Evaluation of Overseas Development Assistance" (Commissioned by The Department of Finance, 2000).

Kesper, A. "Failing or not aiming to grow? Manufacturing SMMEs and their contribution to employment growth in South Africa" (TIPS Working Paper 15, 2000).

Kingdon, G and Knight, J "Quality of Schooling and the Race Gap in Labour Market Outcomes in South Africa" (Presented at the Development Policy Research Unit (DPRU) and Friedrich Ebert Stiftung Second Annual Conference on Labour Markets and Poverty in South Africa, Muldersdrift, Johannesburg, 2002).

Lithelm, A. "Informal retailing through home-based micro-enterprises: the role of spaza shops" (2005) 22 (2) Development Southern Africa 199-214.

Moser, C. "Gender Planning in the Third World: Meeting Practical and Strategic Gender Needs" (1989) 17(11) World Development 1799.

Morris, M. "Informal sector activity as entrepreneurship: insights from a South African township " (January 1995) Journal of Small Business Management 77-86.

Napier, M and Lieberberg, S. "Investigation into entrepreneurs and small scale landlords" (Commissioned by Shisaka Development Services in Association with the CSIR, 2006).

Napier, M and Mothwa, M. "Push and pull factors in the initiation and maintenance of home work in two Pretoria settlements: the myths and realities of South African home-based enterprises" (2001) 12(3) Urban Forum.

Nqelo, N and Malan, L. "Comparative Study for Impact Assessment and Course Design" (Commissioned by the Triple Trust Organisation, 1998).

Orford, J. "The Global Entrepreneurship Monitor": Graduate School of Business, University of Cape Town, ISBN: 0-620-35876-9 (2004).

Qualmann, R. "Pre-study for a sector analysis on economic development and employment promotion in South Africa"(Commissioned by GTZ, Pretoria, 2000).

Qualmann, R. "Sector study on economic development and employment promotion in South Africa" (Commissioned by GTZ, Pretoria, 2000).

Philip, K. "How the structure of the economy impacts on opportunities on the margins" (Presented at "Working on the Margins: Addressing structural poverty 
and exclusion in South Africa" conference hosted by PLAAS and the Chronic Poverty Centre, Cape Town, 25-27 March 2009).

Raynolds, A. "Poverty alleviation through participation in fair trade coffee networks:

existing research and critical issues" (Commissioned by The Community and Resource Development Program, The Ford Foundation, New York, March 2002) Viewed on 13 July 2007at http://www.colostate.edu/dept/Sociology/FairTradeResearchGroup/doc/raybac k.pdf.

Riley, T. "Characteristics of and Constraints Facing Black Businesses in South Africa: Survey Results".World Bank Discussion Paper on the Economy of South Africa No 5 (1993).

Rogerson, C. "Re-thinking the informal economy of South Africa" Development Paper 84, Development Bank of South Africa (DBSA) (1996).

Rogerson, C. Reid, K. Wicksteed, S. "Towards a Framework for Rural Small Business Support in South Africa" (Commissioned by Ntsika Enterprise Promotion Agency, 1997).

Rogerson, C. "Rural SMME Development in South Africa: Contemporary Directions and Policy Frameworks" (Commissioned by GTZ, Pretoria, 2002).

Rogerson, C, “The Impact of the South African Government's SMME Programme: A Ten Year Review" (1994-2003)" (2004)21(5) Development Southern Africa.

Ruiters, A. China, A. Spicer, S. "The functioning of micro enterprises and support services in the Western Cape" (Commissioned by CASE, Cape Town, 1994).

Scoones, I. "Sustainable Rural livelihoods: a framework for analysis" (1998) IDS Working Paper No 72.

Sen, A. Development is Freedom Random House USA, 1999.

Sengupta, A."The Human Right to Development" (2004) 32 Oxford Development Studies 179.

Skinner, C. "Laws Governing Street Trading in South Africa": Unpublished input paper for produced for the Commission on Legal Empowerment for the Poor (2007).

Statistics South Africa "The contribution of small and micro enterprises to the economy of the country: A survey of non-VAT-registered businesses in South Africa" ( 2005); accessed 22 November 2009 at http://www.statssa.gov.za/publications/publicationsearch.asp.

Taskgro "Policy Proposals for Small, Medium and Micro Enterprise Development". (Commissioned by Friedrich Ebert Stiftung, Johannesburg, 1993). 
Tipple, G. "The place of home-based enterprises in the informal sector: evidence from Cochabamba, New Delhi, Surabaya and Pretoria" (2005) 42(4) Urban Studies 611-632.

Trade Industrial Policy Strategy (TIPS) "Second Economy Strategy: Addressing Inequality and Economic Marginalisation: A Strategic Framework": Commissioned by the Office of the Presidency of South Africa (January 2009).

UNDP/SEPED "Private Adjustments: Household responses to the Erosion of Work" (Presented at the he Fourth World Conference on Women (Beijing) and the World Summit for Social Development, Copenhagen, 1999); accessed 29 November 2008 at http://hdr.undp/org/docs/events/global forum/2000/rocha.pdf.

Valodia, I “Economic Policy and Women's Informal and Flexible Work in South Africa" (2001) 32(5) Development and Change 871-892.

Van der Berg, S "The schooling solution: primary school performance is the key". (2005) Susan Brown (ed) Economic Transformation Audit 2005: Conflict and Governance, Institute for Justice and Reconciliation, Cape Town.

Von Broembsen, M "Poverty Alleviation: Beyond the National Small Business Strategy" (2003) IDASA Budget Information Service Occasional Paper http://www.idasa.org.za/ (accessed 14 November 2010).

Von Broembsen, M and Wood, E. Global Entrepreneurship Monitor: South African Executive Report Graduate School of Business, University of Cape Town, ISBN: 0620-35876-9 (2005).

Von Broembsen, Marlese "SMMEs, the Informal Sector and the "Second Economy", (2009) PLAAS Working Paper No 10, www.plaas.org.za (accessed 14 November 2010).

Wittenberg, M. "Conflictual Intra-household allocations" Working Paper No 211 Princeton University, Woodrow Wilson School of Public and International Affairs, Research programme in Development Studies, viewed on 3 October 2009 at http://rdps.princeton.edu/rpds/papers/pdfs/wittenberg.pdf.

Wright, Graham A. "Examining the impact of micro-finance services - increasing income or reducing poverty" (1999)10(1) Small Enterprise Development 38-47. 